Proc. Estonian Acad. Sci. Biol. Ecol., 2003, 52, 2, 134-140

\title{
Changes in the distribution of charophyte species in enclosed seabays of western Estonia
}

\author{
Kaire Torn ${ }^{\mathrm{a}, \mathrm{b} *}$ and Georg Martin ${ }^{\mathrm{a}}$ \\ ${ }^{a}$ Estonian Marine Institute, University of Tartu, Marja 4D, 10617 Tallinn, Estonia \\ ${ }^{\mathrm{b}}$ Institute of Botany and Ecology, University of Tartu, Lai 40, 51005 Tartu, Estonia \\ Received 3 May 2002, in revised form 26 June 2002
}

\begin{abstract}
An overview of the distribution of charophytes in Matsalu, Haapsalu, and Rame bays, western Estonia, is given based on sampling carried out in 2001. Sampling was performed repeating stations investigated during previous investigations. Chara aspera was the most frequent charophyte in the three investigated bays. Compared to the former data, its distribution area has decreased in Matsalu Bay. Chara connivens was found for the first time in Matsalu Bay. No largescale changes in charophyte distribution have occurred in Haapsalu Bay during recent decades. The distribution area of Chara tomentosa in Rame Bay has moved from east towards north.
\end{abstract}

Key words: charophytes, Matsalu Bay, Haapsalu Bay, Rame Bay.

\section{INTRODUCTION}

Charophytes form a highly developed, unique group of algae. Charophytes usually occur in shallow water with soft bottoms. As compared to other Baltic Sea areas, the importance of charophytes is higher in the Estonian coastal ecosystem. This is reflected by their higher frequency of occurrence and greater share in the total phytobenthos biomass (Waern, 1952; Trei, 1983a, 1991a; Kautsky, 1988). This is explained by favourable conditions created by a unique combination of different geomorphological and hydrological factors (Martin et al., 1998).

Although charophytes can be found all around the Baltic a significant decline of both the number of species and their density and/or areal coverage have been observed during the last decades (Blindow, 2001; Dekere, 2001; Schubert \& Yousef, 2001; Sinkeviciene \& Jurgilaite, 2001; Zhakova \& Balashova, 2001).

*Corresponding author, kairet@klab.envir.ee 
Because of the lack of scientific interest in the distribution of charophytes along the Baltic Sea coasts, relevant recent information is missing for most of the area (Dekere, 2001; Nilsen, 2001; Sinkeviciene \& Jurgilaite, 2001; Zhakova \& Balashova, 2001). The same also applies to the Estonian coastal waters (Martin, 2001).

All the investigated bays - Matsalu, Haapsalu, and Rame - are very shallow, with a soft substrate, and relatively sheltered. Hence, they provide an excellent habitat for charophytes. In these bays detailed phytobenthos surveys have been conducted in the past, which enables to reconstruct the temporal trends in the charophyte distribution. The aim of the present study was to describe the changes in the distribution and species composition of charophytes in Matsalu, Haapsalu, and Rame bays.

\section{MATERIAL AND METHODS}

The material was collected in June and July 2001. The total number of stations was 10 in Matsalu Bay, 5 in Haapsalu Bay, and 8 in Rame Bay. Observation sites were chosen to repeat earlier sampling sites (Fig. 1.) Historical data were obtained from the field diaries of T. Trei from investigations carried out in 1962-89.

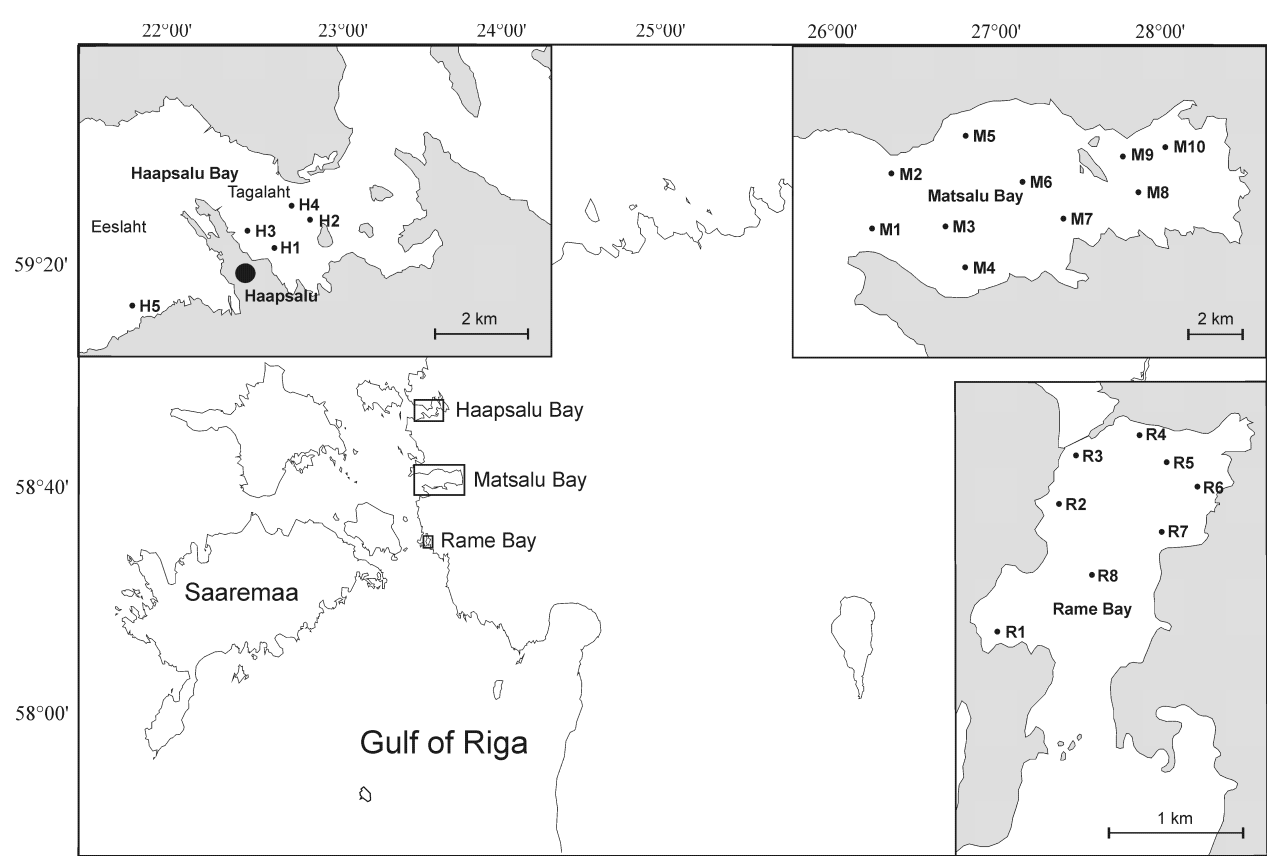

Fig. 1. Location of the investigated areas and sampling sites. 
Sampling was performed by SCUBA diving. For each locality, its GPS position and exact depth were recorded. Among biotic variables the total coverage of benthic vegetation and the coverage of different species were determined at each site. Coverage was estimated visually using percentage scale with $10 \%$ accuracy. From abiotic variables water salinity and bottom composition were recorded. The collected charophytes were packed, labelled, and then frozen until sorting and determination in the laboratory. Determination was made using the determination keys by Blindow \& Krause (1990) and I. Blindow (unpubl.).

\section{RESULTS AND DISCUSSION}

\section{Matsalu Bay}

The sampling depth varied from 0.8 to $4 \mathrm{~m}$. Salinity was recorded to be in the interval of 0.64-4.73 PSU (mostly between 2 and 3 PSU). Muddy sand was prevailing in the eastern part of the bay, sand and sandy clay in the middle part. In the northeastern part of the bay the total coverage of plants was $100 \%$, formed mainly by Chara aspera. In the rest of the bay the total coverage was quite low (5-25\%). During the investigations four species of charophytes were found (Fig. 2a). Charophytes were not found at 2 localities out of 10 .

The benthic vegetation of Matsalu Bay has been described several times from the beginning of the 1960s until the end of the 1980s (Trei, 1965, 1970, 1983b, 1985, 1987, 1991a, b).

Compared to the previous data, the distribution area of the C. aspera community has decreased. In 1984, the C. aspera community was widely spread in the middle and eastern parts of the bay (Trei, 1985, 1991b). Today the area occupied by the community has been reduced mainly to the eastern part, including a small section from the middle of the bay.

Chara connivens, a very rare species in the Baltic Sea, has not been previously recorded from Matsalu Bay. This species occurred in the middle part of the bay where other vegetation was very poor. According to the literature $C$. connivens has previously been found only as single specimens at the southern coast of Saaremaa Island and in the shallow coastal sea of Kihnu Island (Trei, 1991a). In 2001 it was found at several locations in the sea area of the West Estonian Archipelago, and according to present knowledge this species should not be considered as rare any more (authors' pers. obs.).

Chara contraria, a quite unique species for the Estonian coastal sea, occurs mostly in freshwater environments. However, according to different keys (Gollerbach, 1983; Blindow \& Krause, 1990) the specimen found could be identified also as C. baltica in this particular case. Besides Matsalu Bay, this species has been found from brackish water only once from Kuressaare Bay (Trei, 1991a, b). 
(a) Matsalu Bay $\quad 1984 \quad 2001$

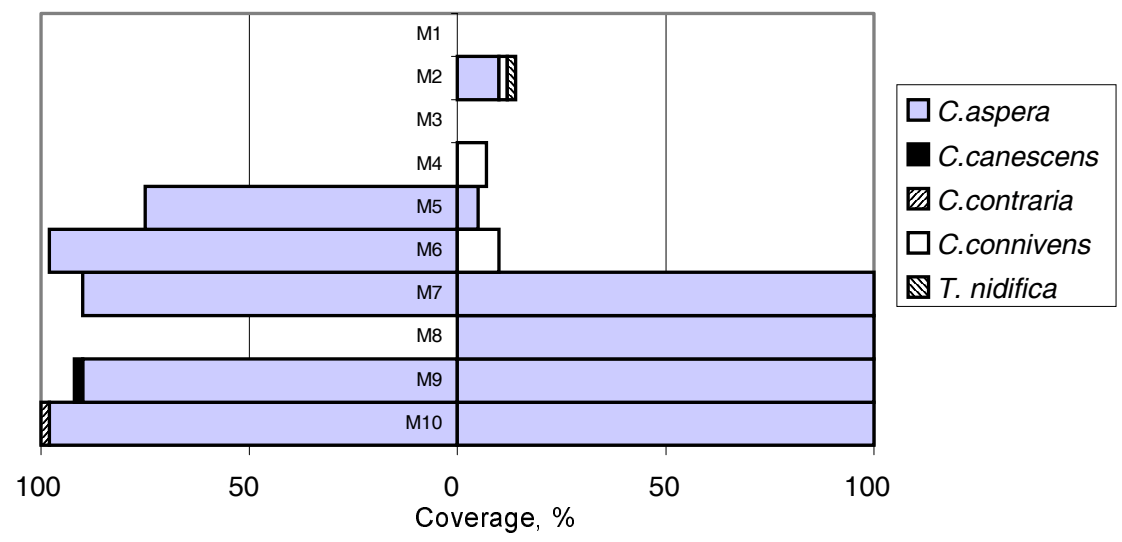

(b) Haapsalu Bay

2001

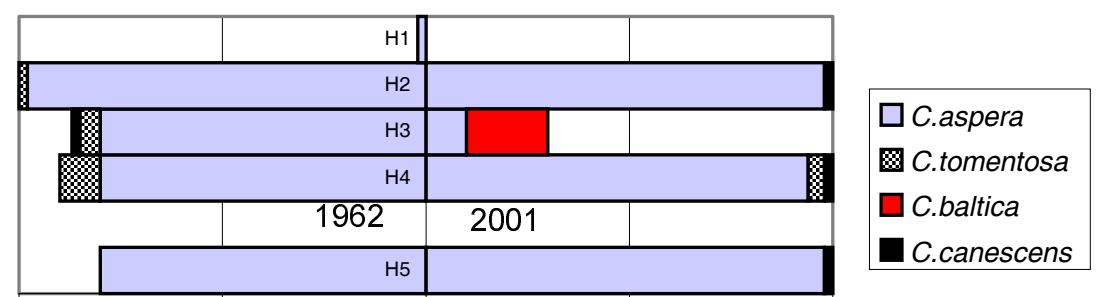

100

50

0

50

100

Coverage, $\%$

(c) Rame Bay

1983

2001

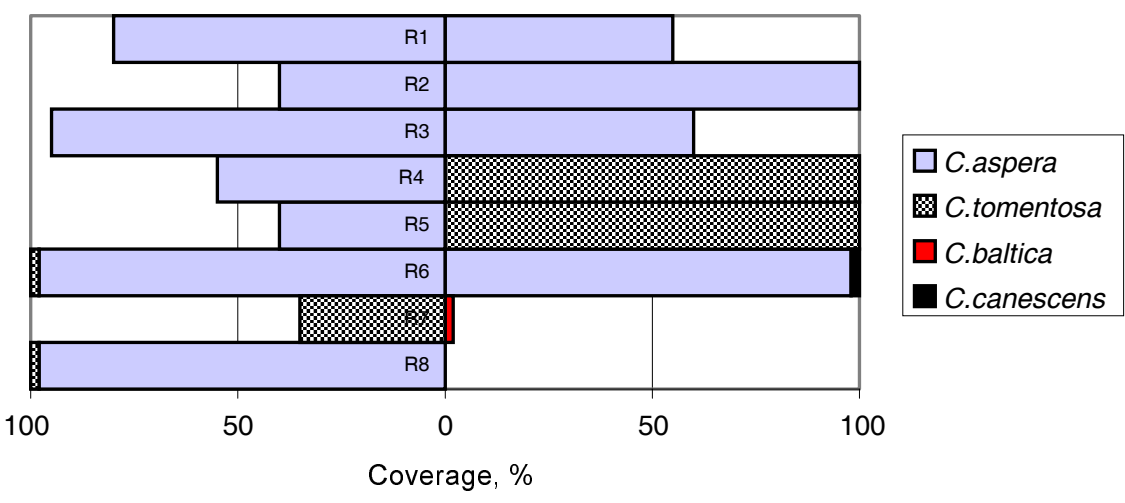

Fig. 2. Coverage of different charophyte species in recent and historical observations. 
Two species, Chara tomentosa, which previously occurred in the eastern part of the bay, and $C$. canescens, usually common in $C$. aspera communities, were not found during the present study.

Single specimens of Tolypella nidifica have been constantly found from the eastern part of the bay (Trei, 1991b).

\section{Haapsalu Bay}

A survey of the benthic vegetation was performed at one location in the part of the bay called Eeslaht (salinity 2.67 PSU) and four locations in the part of the bay called Tagalaht (salinity 1.72-2.27 PSU). All the studied locations were at depths of $0.3-1.6 \mathrm{~m}$ and had sandy or muddy bottom. The vegetation coverage degree was mostly $100 \%$ in Tagalaht (except for the sampling point H1) with a dominating $C$. aspera community. Single specimens of $C$. canescens and $C$. tomentosa were found between dense C. aspera stands (Fig. 2b).

In comparison with the 1960s the distribution area of C. aspera dominated communities had declined in the 1970s. Only fragments of this community were encountered in a limited area and some scattered specimens were found. The biomass and distribution area of $C$. tomentosa had undergone similar changes (Trei, 1965, 1984a, b, 1991a). In 1985 the situation had improved considerably and C. aspera meadows were observed over large areas again (Trei, 1991a).

No big differences in the distribution of charophytes were observed between the years 1985 and 1989. Changes had taken place only at the sampling point H1, which was under a direct influence of a wastewater outlet. At the end of the 1970s disappearance of benthic vegetation was recorded in this area. In 1985 the community of vascular plants had almost restored in this area. In 1989 the bottom was covered with a dense, $30-40 \mathrm{~cm}$ high charophyte community, unfortunately not identified to species level by T. Trei. In 2001 the only plant species found on these bottoms was Myriophyllum spicatum growing in distinct aggregations with a total coverage of $50 \%$.

According to the information available for the last couple of decades no large changes occurred in the distribution of charophytes in Haapsalu Bay. A C. aspera community has been constantly inhabiting the central part of the bay. It includes also some rare specimens of $C$. tomentosa and $C$. canescens. The last time C. baltica was found in Haapsalu Bay before 2001 was in 1962.

\section{Rame Bay}

The stations were located mostly at depths of 1-1.2 m, with salinities between 4.4 and 5.3 PSU. The dominating substrate was muddy sand. The total phytobenthos coverage in the bay was estimated at $15-100 \%$. Charophytes were dominating in most of the cases but in some locations Potamogeton pectinatus was found to be abundant as well. Four species of charophytes were found in 
Rame Bay. The most widespread species was $C$. aspera, which in some places was covered with epiphytic Cladophora glomerata. Single $C$. canescens specimens were also found in C. aspera stands. Single specimens of $C$. baltica were found from the P. pectinatus community. In the northern part of the bay a dense stand (coverage $100 \%$ ) of $C$. tomentosa was identified.

During the years 1962 and 1983 the most abundant community in the bay was that of $C$. aspera, which covered the soft bottom of the entire sheltered part of the bay. Single agglomerations of $P$. pectinatus and $C$. tomentosa were also described. The coverage of $C$. aspera varied in space as well as in time (Fig. 2c). In some occasions single specimens of $C$. canescens were observed in the community. Also some specimens of $T$. nidifica were found during the investigations conducted in 1962 (Trei, 1965, 1983a).

In 1983 C. tomentosa dominated communities were found as patches between C. aspera dominated communities in the eastern part of the bay. According to the data from 2001 this species forms monodominant communities in the northern part of the bay. C. tomentosa has quite an uneven and scarce distribution along the Estonian coastline, independent communities with high biomass and coverage have been reported only from single locations such as the Turja harbour area on the southern coast of Saaremaa Island (authors' pers. obs.) and the eastern part of Matsalu Bay (Trei, 1991a).

\section{CONCLUSIONS}

The present work showed that $C$. aspera is the most frequent plant species in the investigated sea area. While changes in the charophyte distribution could be observed in Matsalu Bay (ocurrence of C. connivens and decline of C. aspera in the area) and Rame Bay (shift in the distribution of C.tomentosa) not any significant changes were recorded in Haapsalu Bay compared to previous investigations.

\section{ACKNOWLEDGEMENTS}

This study was supported by the Estonian Governmental Programme No. 0200792s98. The authors are grateful to Tiiu Trei for making available field diaries from her earlier expeditions. We wish to thank Jonne Kotta for comments on the manuscript. We are also grateful to Irmgard Blindow for help with charophyte determination.

\section{REFERENCES}

Blindow, I. 2001. Charophytes along the Swedish coast: occurrence and ecology. Schriftenr. Landschaftspflege Naturschutz, 72, 39-40.

Blindow, I. \& Krause, W. 1990. Bestämningsnyckel för svenska kransalger. Sven. Bot. Tidskr., 84, 119-160. 
Gollerbach, M. 1983. Determination Key of Freshwater Algae of USSR. Nauka, Leningrad (in Russian).

Dekere, Z. 2001. Charophytes and their habitats along the Latvian coast. Schriftenr. Landschaftspflege Naturschutz, 72, 19-21.

Kautsky, H. 1988. Factors Structuring Phytobenthic Communities in the Baltic Sea. University of Stockholm.

Martin, G. 2001. Distribution of Charophytes in Estonian coastal waters. Schriftenr. Landschaftspflege Naturschutz, 72, 31-36.

Martin, G., Palo, A. \& Möller, K. 1998. Introduction to the marine and coastal environment of Estonia. Baltic Sea Environ. Proc., 75, 30-34.

Nilsen, R. 2001. The Danish Charophytes. Schriftenr. Landschaftspflege Naturschutz, 72, 37-38.

Schubert, H. \& Yousef, M. A. M. 2001. Charophytes in the Baltic Sea - threats and conservation. Schriftenr. Landschaftspflege Naturschutz, 72, 7-8.

Sinkeviciene, Z. \& Jurgilaite, D. 2001. Historical and new data on Charophytes in Lithuanian waters of the Baltic Sea. Schriftenr. Landschaftspflege Naturschutz, 72, 17-18.

Trei, T. 1965. Materjale Väinamere põhjataimestiku ja töönduslike punavetikate kasutamise võimaluste kohta. Eesti NSV TA Toim. Biol., 14, 180-196.

Trei, T. 1970. Väinamere põhjataimestik. In Lääne-Eesti rannikualade loodus (Kumari, E., comp.), pp. 27-40. Valgus, Tallinn.

Trei, T. 1981. Saastumise toimest põhjataimestiku levikule Haapsalu lahes. In Inimtegevus ja keskkonnakaitse. Teaduslik-praktiline konverents (Ratas, R., ed.), pp. 76-78. Acad. Sci. Estonian SSR, Tallinn.

Trei, T. 1983a. Mändvetiktaimed meres. Eesti Loodus, 26, 521-526.

Trei, T. 1983b. The species composition of phytobenthos in some shallow parts of western Estonia. Eesti NSV TA Toim. Biol., 32, 245-253 (in Russian).

Trei, T. 1984a. Long-term changes in the bottom flora of Haapsalu Bay. Limnologica, 15, 351-352.

Trei, T. 1984b. The influence of human activity upon the bottom vegetation in some shallow bays of western Estonia. In Hydrobiological Regime of the Baltic Sea (Järvekülg, A., comp.), pp. 74-81. Tallinn (in Russian).

Trei, T. 1985. Matsalu lahe veetaimestik. In Matsalu - rahvusvahelise tähtsusega märgala (Kumari, E., comp.), pp. 44-52. Valgus, Tallinn.

Trei, T. 1987. Plant communities in Matsalu Bay in 1984. Loodusvaatlusi, I, 46-59.

Trei, T. 1991a. Taimed Läänemere põhjal. Valgus, Tallinn.

Trei, T. 1991b. Matsalu lahe põhjataimestik. Tallinn.

Waern, M. 1952. Rocky shore algae in the Öregrund archipelago. Acta Phytogeogr. Suec., 30.

Zhakova, L. \& Balashova, N. 2001. Charophytes of the Leningrad Region, Russia. Schriftenr. Landschaftspflege Naturschutz, 72, 23-26.

\title{
Mändvetikate leviku muutused Lääne-Eesti suletud lahtedes
}

\author{
Kaire Torn ja Georg Martin
}

On antud ülevaade mändvetikate levikust Matsalu, Haapsalu ja Rame lahes. Uuritud lahtedes oli kõige sagedamini esinevaks mändvetikaks Chara aspera. Võrreldes varasemate andmetega oli $C$. aspera levikuala Matsalu lahes kahanenud. Samas lahes leiti esimest korda liiki Chara connivens. Haapsalu lahes ei olnud viimaste aastakümnete jooksul mändvetikate levikus olulisi muutusi toimunud. Rame lahes oli Chara tomentosa levikuala muutnud oma asukohta. 